$7-2010$

\title{
Taking Conventional Truth Seriously: Authority Regarding Deceptive Reality
}

Jay L. Garfield

Smith College, jgarfield@smith.edu

Follow this and additional works at: https://scholarworks.smith.edu/phi_facpubs

Part of the Philosophy Commons

\section{Recommended Citation}

Garfield, Jay L., "Taking Conventional Truth Seriously: Authority Regarding Deceptive Reality" (2010). Philosophy: Faculty Publications, Smith College, Northampton, MA.

https://scholarworks.smith.edu/phi_facpubs/21 


\section{UNIVERSITY of \\ HAWAI'I \\ PRESS}

TAKING CONVENTIONAL TRUTH SERIOUSLY: AUTHORITY REGARDING DECEPTIVE

\section{REALITY}

Author(s): Jay L Garfield

Source: Philosophy East and West, Vol. 60, No. 3 (JULY 2010), pp. 341-354

Published by: University of Hawai'i Press

Stable URL: https://www.jstor.org/stable/40666588

Accessed: 03-08-2018 14:08 UTC

JSTOR is a not-for-profit service that helps scholars, researchers, and students discover, use, and build upon a wide range of content in a trusted digital archive. We use information technology and tools to increase productivity and facilitate new forms of scholarship. For more information about JSTOR, please contact support@jstor.org.

Your use of the JSTOR archive indicates your acceptance of the Terms \& Conditions of Use, available at https://about.jstor.org/terms

University of Hawai'i Press is collaborating with JSTOR to digitize, preserve and extend access to Philosophy East and West 


\title{
TAKING CONVENTIONAL TRUTH SERIOUSLY: AUTHORITY REGARDING DECEPTIVE REALITY
}

\author{
Jay L Garfield \\ Smith College, University of Melbourne, Central University of Tibetan Studies
}

\section{The Problem}

Tsong khapa, following Candrakīrti closely, writes that "Convention'1 refers to a lack of understanding or ignorance; that is, that which obscures or conceals the way things really are" (Ocean of Reasoning 480-481). ${ }^{2}$ Candrakīrti himself puts the point this way:

\begin{abstract}
Obscurational truth ${ }^{3}$ is posited due to the force of afflictive ignorance, which constitutes the limbs of cyclic existence. The śrāvakas, pratyekabuddhas and bodhisattvas, who have abandoned afflictive ignorance, see compounded phenomena to be like reflections, to have the nature of being created; but these are not truths for them because they are not fixated on things as true. Fools are deceived, but for those others-just like an illusion-in virtue of being dependently originated, they are merely obscurational. ( $d B u$ ma 'a 255a; Ocean $481-482)^{4}$
\end{abstract}

So it might seem that for Candrakīrti and Tsong khapa that conventional truth (understood here as obscurational truth) is merely illusion, wholly false, accepted only by the fools it deceives.

But of course that can't be the whole story, for several reasons. First of all, both Candrakirti and Tsong khapa refer to conventional truth as a truth. Indeed, in Madhyamakāvatāra VI:24 and its commentary, Candrakīrti explicitly argues that there is a big difference between conventional truth and conventional falsehood. Second, they also indicate that the term "convention," although it can mean concealing (Prasannapadā 439), can also refer to mutual dependence and to signifiers (Ocean 480; MavB 252b; Prasannapadā 439-440). In Prasannapadā, Candrakīrti emphasizes the presence of these more positive meanings, asserting that "positing the person as a dependent designation based upon the aggregates" is an example of mundane convention (439) and that mutual dependence is a meaning of "conventional," and that therefore "term and referent, consciousness and object of knowledge, and all such things, so long as they are non-deceptive, should be known as conventional truth" (440). ${ }^{5}$

Third, Candrakirti also asserts that "It has been shown that each phenomenon has its own two natures-a conventional and an ultimate nature" (sDe dge 253a/2003, p. 483). ${ }^{6}$ The fact that these are natures of phenomena means that they are, in some sense, both existent. In fact, the very fact that Candrakirti refers to these as natures of objects indicates that he does not reduce the sense of "conventional" (samvrti, vyavahāra) to illusory. Fourth, Nāgārjuna asserts quite plainly, in the verse to which 
all of the passages to which I have just adverted are commentaries, that "the Buddha's teaching is based on two truths: a truth of worldly convention and an ultimate truth" (MMK XXIV:8; Ocean 479). Finally, given the doctrine of the identity of the two truths (MMKXXIV:18-19), a doctrine of which both Tsong khapa and Candrakirti approve, if the ultimate truth is a truth, a conventional truth that is identical with it just has to be true in some sense.

I am interested specifically in how Candrakīrti and Tsong khapa understand the idea of conventional truth, most specifically in the sense in which, and the reasons for which, they regard conventional truth as true. We must therefore reconcile the claims that conventional truth is concealing, deceptive, truth only for fools with its identity with ultimate truth, and its being one of the two natures of any object. We thus also must explain the sense in which conventional truth is distinct from, and the sense in which it is identical to, ultimate truth, and why these two claims are mutually consistent.

I am interested in the work of Candrakīrti because I think that he, more than any other Indian Mādhyamika, worries about how to interpret this doctrine, and thinks it through with more clarity than any other Indian commentator on Nāgārjuna. I am interested in the work of Tsong khapa, because I think that he, more than any other commentator on Indian Madhyamaka, understood and appreciated the force of Candrakīrti's analysis and took seriously the implications of taking conventional truth seriously for Buddhist epistemology and practice. If we can make sense of the doctrine of the two truths and of the reality of the conventional despite its implication with primal ignorance at all, we can make sense of it in the context of the work of these two philosophical giants.

\section{Two Reasons that Conventional Truth is a Truth (Preliminaries)}

I begin by noting two prima facie reasons for treating conventional truth as a truth in the work of both Candrakirti and Tsong khapa. ${ }^{7}$ First, there is a very important sense in which the conventional truth is the only truth that there is. There are two ways of making this point. First, as we noted above, the two truths are, in some sense, identical. If that is true, then even ultimate truth is only conventional. The second way to make this point is this, though: the ultimate truth is emptiness, the absence of true, or inherent, existence in things. The ultimate truth is thus the fact that they are merely conventionally existent. Neither Tsong khapa nor Candrakirti would put the point this way. Tsong khapa argues, following Candrakīrti very closely, that the ultimate truth-emptiness-is an external negation, a mere elimination of any intrinsic existence in things, and of any conceptualization (Ocean 52-23). But this in the end amounts to the same thing, since to be merely existent is to lack any intrinsic identity. The ultimate truth is, hence, even for Tsong khapa, that the conventional truth is all that there is. We will return to this consideration at the end of this essay.

The second reason will occupy more of my analytic attention in what follows. Tsong khapa and Candrakirti each emphasize that conventional truth is the domain of conventional authoritative cognition, and hence that conventional truth is a do- 
main about which there is a difference between getting it wrong and getting it right, and that one can be correct about conventional truth, in two different but equally important senses. First, ordinary people can be right about the fact that there is a rope on the ground, wrong about the fact that there is a snake there. That there is a rope, not a snake, is, hence, in some sense true. Second, as we have seen, āryas can know the conventional nature of conventional reality in a way that ordinary fools cannot. What is deceptive to fools is not deceptive to āryas, although it is merely conventional. In that sense, too, convention can be seen truly.

The important point here, and the principal topic of this essay, is that for both Candrakirti and Tsong khapa, it is the fact of epistemic authority that guarantees truth in convention and the reality of the conventional. When we ask why is conventional truth a truth, the answer will turn on the fact that there is a difference to be drawn within the conventional between truth and falsehood, as well as a truth about the conventional. There is something that counts as getting it right about conventional reality.

\section{Interlude: Epistemic Authority for Mādhyamikas}

Inasmuch as the role of the authority of epistemic instruments in Mādhyamaka metaphysics will play a significant role in the following discussion, a few remarks on Nāgārjuna's and Candrakīti's attitudes toward these instruments and their authority are necessary. It is often urged that Nāgārjuna, in the Vigrahavyāvārtanī, rejects the intelligibility of any epistemic instruments. I believe that this is incorrect. Nāgārjuna, in that text, takes on a Nyāya account of epistemic instruments and their authority according to which the instruments are taken to be foundational to all knowledge. He does so because this kind of foundationalism ${ }^{8}$ would require their intrinsic identity and authority as instruments, and so would undermine his account of emptiness.

The Nyāyā interlocutor in the Vigrahavyāvārtani argues that Nāgārjuna himself cannot argue cogently for his own position, as that would presuppose that it is delivered and so justified by an epistemic instrument; that, in turn, the interlocutor argues, requires that the instruments be self-verifying and hence non-empty. Hence, he argues, Nāgārjuna must presuppose non-empty epistemic categories in order to argue for the emptiness of everything, and so is self-refuting.

$\mathrm{V}$

Suppose one were to deny the things

One apprehended through perception.

That by which one apprehended things-

Perception itself-would be nonexistent ${ }^{9}$

That is, as the autocommentary makes clear, the opponent is arguing that any argument for the emptiness of the objects of knowledge is an equally good argument for the emptiness of the instruments of knowledge. But if the instruments are empty, they cannot serve as foundations for knowledge, and so, in the absence of such foundations, there would be no reason to believe even the Mādhyamika's claims. ${ }^{10}$ 
Nāgārjuna replies not by denying the utility of the epistemic instruments, but rather by arguing, in what must be the first explicit defense of epistemological coherentism ${ }^{11}$ in the history of world philosophy, that these instruments are themselves useful precisely because they are dependent. They are dependent upon their epistemic objects, the objects of knowledge:

$\mathrm{XL}$

If epistemic instruments were self-established,

They would be independent of epistemic objects.

These epistemic instruments you would establish,

Being self-established, would depend on nothing else.

$\mathrm{XLI}$

If, as you would have it, the epistemic instruments

Are independent of their objects, the epistemic objects

Then these epistemic instruments

Would pertain to nothing at all. ${ }^{12}$

$\mathrm{XLVI}$

So, as far as you are concerned, by establishing the epistemic instruments

The epistemic objects are thereby established.

So, as far as you are concerned,

Neither epistemic instruments nor epistemic objects can be established. ${ }^{13}$

Foundationalism, even of this methodological kind, according to Nāgārjuna, makes no sense. Neither instrument nor object of knowledge can serve as foundations. We are entitled to rely on epistemic instruments, that is, just because they deliver epistemic objects; we are entitled in turn to confidence in our judgments about our epistemic objects just because they are delivered by these epistemic instruments. You are entitled to believe that your vision is good just because it delivers visible objects to you; you are entitled to believe that these objects are present just because your vision is good.

Candrakīrti, in the Prasannapadā, is even more explicit in his endorsement of the Nyāya set of epistemic instruments (perception, inference, analogy, and scriptural authority). He enumerates them specifically, but argues that they have only a dependent, conventional validity, concluding: "therefore, in this context [that of mundane knowledge] the four epistemic instruments make mundane object[s] known" (Prasannapadā 55). ${ }^{14}$ And of course, Tsong khapa makes explicit use of this theory of epistemic instruments and objects, using this theory as an account of authority or warrant throughout his corpus. It is therefore a serious mistake to think that Mādhyamaka, at least as articulated by Nāgārjuna, Candrakīrti, and Tsong khapa, eschews reliance on, or an account of, epistemic authority.

Mirages for Mādhyamikas

Among the many similes for conventional truth that litter Mãdhyamaka texts, the most fruitful is that of the mirage. Conventional truth is false, Candrakīrti tells us, 
because it is deceptive (Yuktiśasțikavrtti dBu ma ya 7b). Candrakīrti spells this out in terms of a mirage. A mirage appears to be water, but is in fact empty of water-it is deceptive and, in that sense, a false appearance. On the other hand, a mirage is not nothing: it is an actual mirage, just not actual water.

The analogy must be spelled out with care to avoid the extreme of nihilism. A mirage appears to be water, but is only a mirage; the inexperienced highway traveler mistakes it for water, and for him it is deceptive, a false appearance of water; the experienced traveler sees it for what it is-a real mirage, empty of water. Just so, conventional phenomena appear to ordinary, deluded beings to be inherently existent, whereas in fact they are merely conventionally real, empty of that inherent existence; to the āryas, on the other hand, they appear to be merely conventionally true, hence to be empty. For us, they are deceptive, false appearances; for them, they are simply actual conventional existents.

We can update the analogy to make the point more plainly. Imagine three travelers along a hot desert highway. Alice is an experienced desert traveler; Bill is a neophyte; Charlie is wearing polarizing sunglasses. Bill points to a mirage up ahead and warns against a puddle on the road; Alice sees the mirage as a mirage and assures him that there is no danger. Charlie sees nothing at all, and wonders what they are talking about. If the mirage were entirely false-if there were no truth about it at all, Charlie would be the most authoritative of the three (and Buddhas would know nothing of the real world). But that is wrong. Just as Bill is deceived in believing that there is water on the road, Charlie is incapable of seeing the mirage at all, and so fails to know what Alice knows - that there is an actual mirage on the road, which appears to some to be water, but which is not. There is a truth about the mirage, despite the fact that it is deceptive, and Alice is authoritative with respect to it precisely because she sees it as it is, not as it appears to the uninitiated.

\section{A Message from our Sponsors: Candrakīrti and Tsong khapa}

Let's now consider a few crucial passages from the relevant texts to get a better sense of the constraints that an account of Mādhyamaka theory of conventional truth must satisfy. Tsong khapa, in his discussion of the status of arising and ceasing, et cetera, in the context of the negations presented in the Homage verses for Mülamadhyamakakārikā, remarks:

[I]f there were no place for conventional phenomena, the existence of which is established by the epistemic instruments, these phenomena would be like the snake-that is, the rope grasped as a snake- of which no cause or effect is possible....

[I]f one were forced to maintain that there is no place for bondage, liberation, etc in the meaning of "conventional existence," and that these must be placed only in the erroneous perspective, that would be a great philosophical error.

Even worse, as long as convention is conceived [as entirely nonexistent], since there would be no role for the epistemic instruments, neither the proposition maintained nor the person who maintains it nor the proof-including scriptural sources and reasoning- 
could be established by epistemic instruments. So it would be ridiculous to maintain that there are no genuine phenomena delivered by the epistemic instruments. (Ocean $30-31)^{15}$

Tsong khapa makes it plain here that conventional phenomena, unlike the snake thought to be perceived when one sees a rope, have causes and effects, and are actual. Moreover, he argues that the repudiation of the reality of the conventional would undermine the possibility of epistemic authority, undermining even the ability to argue cogently that the conventional does not exist. Such a position would be self-refuting. Returning to the discussion of $M M K X X I V: 8$, Tsong khapa, citing Candrakirti, emphasizes the deceptive side of the conventional:

Suppose someone asks, "what is conventional and what is truth?" The convention from the perspective of which such things as form are posited as true is the ignorance which fabricates the intrinsic existence of phenomena which do not inherently exist.... Thus Madhyamakāvatāra says:

Since the nature of confusion is to veil, it is obscurational.

That which is created by it appears to be truly existent.

The sage has said that it is the obscurational truth.

Created phenomena are obscurational. (VI:28) ${ }^{16}$

Here Madhyamakāvatāra-bhāṣya says:

Obscurational truth is posited due to the force of afflictive ignorance, which constitutes the limbs of cyclic existence. The śrāvakas, pratyekabuddhas and bodhisattvas, who have abandoned afflictive ignorance, see compounded phenomena to be like reflections, to have the nature of being created; but these are not truths for them because they are not fixated on things as true. Fools are deceived, but for those others-just like an illusionin virtue of being dependently originated, they are merely obscurational. (255a; Ocean 481-482)

There are subtle philosophical distinctions to be drawn here. On the one hand, conventional truth is obscurational, confusing and veiling. The reason for this is that conventional reality appears to most of us as though it is truly (inherently) existent-as more than merely conventional. Those who have transcended afflictive ignorance, Candrakirti emphasizes, in fact do see the compounded phenomena comprised by conventional reality, but see them as mirage-like, as actual, but deceptive.

Tsong khapa comments that this means that ignorance is not a necessary condition of positing conventional truth, but that ignorance is instead the source of the superimposition of inherent existence on that which is conventionally existent:

This does not demonstrate that those who posit the existence of conventional truth posit through ignorance, nor that from the perspective of the śrāvakas, pratyekabuddhas and bodhisattvas ... it is not posited as conventional truth... Since it is through afflictive ignorance that one grasps things as truly existent, the object that is thereby grasped cannot exist even conventionally, and whatever is an obscurational truth must exist conventionally. 
... When it is said that compounded phenomena are "merely conventional" from their perspective, the word "mere" excludes truth, but in no way excludes conventional truth. ... Thus, the sense in which the conventional truth is true is that it is true merely from the perspective of ignorance-that is, obscuration.

[When] Candrakīrti ... says, "since it is conventionally true, it is obscurational truth" [MVb 254b] [he] means that conventional truth is that which is true from the perspective of ignorance-obscuration-but not that it is truly existent from the standpoint of nominal convention. (Ocean 482) ${ }^{17}$

Tsong khapa next turns to the question of whether the distinction between conventional and ultimate truth is drawn on the basis of two distinct perspectives on the same reality, or on the basis of two distinct natures of that reality. Following Candrakirti he adopts the latter position, arguing that when we distinguish conventional from ultimate truth we are distinguishing between two aspects of the object, not between two ways of apprehending the object, despite the fact that we indeed apprehend these aspects by using different faculties:

Each of the internal and external phenomena has two natures: an ultimate and a conventional nature. The sprout, for instance, has a nature that is found by a rational cognitive process, which sees the real nature of the phenomenon as it is, and a nature that is found by a conventional cognitive process, which perceives deceptive or unreal objects. The former nature is the ultimate truth of the sprout; the latter nature is the conventional truth of the sprout.

[Candrakīrti's assertion that] "It has been shown that each phenomenon has two natures-a conventional and an ultimate nature" [MVb 253a] does not show that a single nature is in fact two truths in virtue of the two perspectives of the former and latter cognitive process.

The distinction between the two natures, or two truths about a phenomenon, is drawn, on the other hand, according to both Tsong khapa and Candrakīrti, on the basis of the kind of epistemic instrument appropriate to each, and it is important that there is a kind of epistemic instrument that is authoritative with respect to each. To be empty and to be deceptive are different. It is one thing for a mirage to be empty of water; it is another thing for it to be a deceptive appearance. These are two natures of the mirage, and the distinction between them is not the difference between two perspectives on the mirage, but between two objects of knowledge, which in turn are apprehended through different cognitive processes.

When one perceives the emptiness of a phenomenon, one perceives a nature that that phenomenon has, regardless of one's perspective on it, and the kind of cognitive process that perceives that emptiness is one that is authoritative with respect to ultimate truth; when one perceives the conventional character of a phenomenon, one perceives its deceptive nature, both the way it appears and the fact that it does not exist in that way, and the kind of cognitive process that perceives that is one that is authoritative with respect to the conventional. On the other hand, to perceive a conventional phenomenon as inherently existent is not even to be authoritative with respect to the conventional: 
In order to ascertain a pot for instance, as a deceptive or unreal object, it is necessary to develop the view that refutes ... the object of fixation that is the object grasped as truly existent. This is because without having rationally refuted its true existence, its unreality is not established by epistemic instruments. So, for the mind to establish anything as an object of conventional truth, it must depend on the refutation of its ultimate existence. (Ocean 483)

Ordinary beings grasp such things as pots as truly existent, and grasp them as ultimately existent as well. Therefore, from the perspective of their minds, such things as pots are ultimately existent, but they are not conventional objects. The things, such as pots, which are ultimately existent from their perspective, are conventional objects from the perspective of the āryas, to whom they appear as illusionlike. Since they cannot be posited as truly existent as they are apprehended by an āryan consciousness, they are referred to as merely conventional. (Ocean 484)

That which is perceived by ordinary people

By being grasped through unimpaired sense faculties

Is regarded by ordinary people as real.

All the rest is said to be unreal. (MAV VI:25) $)^{18}$

Finally, there is a standard of correctness for conventional truth. Truth, for Candrakirti and for Tsong khapa, must contrast with falsehood. And the standard for the truth of a judgment regarding conventional truth is that it is vouchsafed by the authority of conventional epistemic instruments and cannot be undermined by those instruments, just as the standard of truth of a judgment regarding the ultimate is that it is vouchsafed by the authority of ultimate epistemic instruments and not undermined by cognition of that kind. This in turn requires a distinction between sound and impaired conventional faculties:

The internal impairments of the sense faculties are such things as cataracts, jaundice, and such things as hallucinogenic drugs one has consumed. The external impairments of the sense faculties are such things as mirrors, the echoing of sounds in a cave, and the rays of the autumn sun falling on such things as white sand. Even without the internal impairments, these can become the causes of grasping of such things as mirages, reflections and echoes as water, etc. ...

The impairments of the mental faculty are ... such things as erroneous philosophical views, fallacious arguments and sleep....

Taking conventional objects grasped by such unimpaired and impaired cognitive faculties to be real or unreal, respectively, merely conforms to ordinary cognitive practice. This is because they actually exist as they appear or do not, according to whether or not they are undermined by ordinary cognition. This distinction is not drawn from the perspective of the āryas. This is because just as such things as reflections do not exist as they appear, such things as blue, that appear to exist through their own characteristics to those who are afflicted by ignorance, do not actually exist as they appear. Therefore there is no distinction between those two kinds of cognitive faculties in terms of whether or not they are erroneous. (Ocean 485) 
Note the emphasis on ordinary cognitive practice. Conventional truth, according to Tsong khapa, is that which is delivered by unimpaired cognitive faculties when they are used properly. This is not an accidental generalization; instead it is constitutive of conventional truth. It entails that any judgment about truth is in principle revisable, but that, to be true, is to endure through revision. But the distinction between the conventionally true and the conventionally false has nothing to do with ultimate truth. Conventional existents and conventional non-existents are all ultimately deceptive, all false from the ultimate perspective. Those who are taken in by the conventional fail to understand its deceptive character, and so fail to understand the two truths.

\section{The Centrality of Epistemic Authority}

The authority of the epistemic instruments is hence central to the story that Candrakīrti tells on Tsong khapa's interpretation, and that is so in two respects. First, conventional truth is conventionally true precisely because it is that which is delivered by conventional epistemic instruments and not undermined by it. Without an antecedent account of these instruments and their authority, there is no way to distinguish conventional truth from conventional falsity. On the one hand, without such an account, we might take only the ultimate epistemic instruments to be authoritative. But then, since all phenomena are ultimately unreal, reliance on these instruments only would deliver the verdict that everything is false, and we would have no domain of truth whatsoever. On the other hand, in the absence of such an account, we might take the object of any cognition to be conventionally existent. But that would make a hash of all inquiry, as there is always somebody crazy or deluded enough to believe, or to believe in, anything. It is therefore the fact of conventional authority, of the robustness of ordinary epistemic standards, that allows us to distinguish truth from falsity and to engage in inquiry in the first place.

Second, the genuine actuality of conventional truth, as opposed to a status simply as an object of deluded thought, is a consequence of the fact that the epistemic instruments of àryas-of those who have transcended the primal ignorance that fabricates inherent existence-deliver conventional phenomena, as actual, although deceptive, phenomena. Once again, the authoritative status of their epistemic instruments doesn't so much reflect the fact that it is true that conventional phenomena are existent but that it constitutes their existence, as it constitutes a standard by means of which we can distinguish the true from the false.

Truth for Candrakirti and Tsong khapa is always that which is delivered by authoritative epistemic instruments. But what makes these instruments authoritative? Here is where the epistemic rubber hits the soteriological marga and where the term "conventional" (vyāvahāra, tha snyad) gets its punch. An ultimate epistemic instrument is simply defined as one that is authoritative with respect to ultimate truth. It is hence the kind of cognition finally necessary to attain awakening and is engaged in awakened consciousness. A conventional epistemic instrument, much more straightforwardly, is just one that is authoritative with regard to what we conventionally 
accept. As we have seen, Nāgārjuna argues persuasively in the Vigrahavyāvartani that this is not a static set: epistemic instruments depend for their authority on their epistemic objects, and the objects, in turn, depend for their actuality on the instruments, in a coherentist spiral that defies grounding, but characterizes epistemic practice in the only way we could ever hope to do so. Candrakīrti follows Nāgārjuna in accepting the authority of conventional epistemic instruments in the conventional domain.

\section{Seeing Mirages Correctly}

We can now see why it is so important to see mirages, and to see that mirages are mirages. Mirages are genuine parts of our world, and they cause real problems. If one were to spend one's life in polarizing sunglasses, one would never know this, and one would be less useful to everyone else. (Of course if we evolved with polarizing eyes, like some birds, there would be no mirages.) To see a mirage as water is not to see conventional truth, but conventional falsehood, for conventional epistemic instruments undermine the assertion that there is water on the road. But conventional epistemic instruments vindicate the claim that there is a mirage that appears to be water. That is why it is conventionally existent.

There are two levels of apprehension of mirages, though. There is a difference between the novice desert driver who sees the mirage as water but then infers its mirage status and the experienced driver who sees it as a mirage. They each apprehend conventional existence, but the first does so as do most of us ordinary, but sophisticated Mādhyamikas: inferentially. The latter sees conventional existence as an ārhat-immediately, perceptually, non-inferentially. We see it as deceptive because we are, at least in the first moment of perceptual consciousness, deceived. She sees it as deceptive because she knows what it is like to be us. The transcendence of ignorance is hence not the transcendence of the apprehension of the conventional, but the transcendence of deception by it.

Buddhism is about solving a problem - the problem of the omnipresence of suffering-and the central intuition of Buddhism is that the solution to that problem is the extirpation of ignorance. Epistemology is located at the foundation of morality, and gets its point just from that location. The mechanism of the extirpation of ignorance is the competent use of our authoritative epistemic instruments. What that use delivers is hence, at least indirectly, always of soteriological significance-always instrumental to liberation. Inasmuch as that is the central moral virtue, and inasmuch as epistemology is so tightly bound to the soteriological project, it is also the central epistemic virtue, and what we call the goal of epistemic activity is truth. Conventional truth is hence not to truth as blunderbusses are to buses, nor as fake guns are to real guns, but rather is, instead, simply one kind of truth.

\section{The Identity and Difference of the Two Truths}

One of the Buddha's deepest insights was that there are two truths, and that they are very different from one another. They are the objects of different kinds of cogni- 
tion, and they reflect different aspects of reality. They are apprehended at different stages of practice. Despite the importance of the apprehension of ultimate truth, one can't skip the conventional. Despite the soteriological efficacy of ultimate truth, even after Buddhahood, omniscience and compassion require the apprehension of the conventional.

Nāgārjuna's deepest insight was that despite the vast difference between the two truths in one sense, they are in an equally important sense identical. We can now make better sense of that identity, and of why the fact of their identity is the same fact as that of their difference. The ultimate truth is, as we know, emptiness. Emptiness is the emptiness not of existence but of inherent existence. To be empty of inherent existence is to exist only conventionally, only as the object of conventional truth. The ultimate truth about any phenomenon, according to the analysis I have been defending, is hence that it is merely a conventional truth. Ontologically, therefore, the two truths are absolutely identical. This is the content of the idea that the two truths have a single basis, which is empty phenomena. Their emptiness is their conventional reality; their conventional reality is their emptiness.

But to know phenomena conventionally is not to know them ultimately. As objects of knowledge-that is, as intentional contents of thought, as opposed to as mere phenomena-that is, as external objects considered independently of their mode of apprehension - they are objects of different kinds of knowledge, despite the identity at a deeper level of these objects. Thus the difference. But the respect in which they are different and that in which they are identical are, despite their difference, also identical. A mirage is deceptive because it is a refraction pattern, and it is the nature of a refraction pattern to be visually deceptive. The conventional truth is merely deceptive and conventional because, upon ultimate analysis, it fails to exist as it appears - that is, because it is ultimately empty. It is the nature of the conventional to deceive. Ultimately, since all phenomena, even ultimate truth, exist only conventionally, conventional truth is all the truth there is, and that is an ultimate, and therefore a conventional, truth. To fail to take conventional truth seriously as truth is therefore not only to deprecate the conventional in favor of the ultimate, but to deprecate truth per se. In that way lies suffering.

Notes

I thank two anonymous referees for Philosophy East and West for valuable critique of an earlier draft of this essay as well as the members of the Five College Buddhist Studies Faculty Seminar and especially the Cowherds, for valuable comments on earlier drafts.

1 - There is a translational problem posed throughout this essay by the terms vyāvahāra and samvrti in Sanskrit and tha snyad and kun rdzob in Tibetan. I will use "convention" to translate the first members of these pairs and "obscuration" to translate the second. The only time that this difference is important is where 
they are glossed. Both Candrakirti and Tsong khapa regard them as absolutely coextensive.

2 - All quotations are from Tsong khapa, Ocean of Reasoning, trans. N. Samten and J. Garfield (New York: Oxford University Press) (hereafter Ocean), or from the dDe dge edition of the Tibetan canon.

3 - Here I am using the term obscurational truth instead of the normal conventional truth to reflect the gloss Candrakīrti is developing for the Sanskrit samvrti. In general, in this chapter, as we will be occasionally referring to his and Tsong khapa's gloss of this term, we will require this alternative translation to make sense of what they are doing.

4 - de Itar na re zhig srid pa'i yang lag gis yongs su bsdus pa nyon mongs pa can gyi ma rig pa'i dbang gis kun rdzob kyi bden pa rnam par gzhag go// de la nyan thos dang rang sangs rgyas dang byang chub sems dpa' nyon mongs ba can gyis gzigs pa spangs pa/ 'du byed gzugs brnyan la sogs pa'i yod pa nyid dang 'dra bar gzigs pa rnams la ni bcos ma'i rang bzhin gyi bden pa ma yin te/ bden par mngon par rlom pa med pa'i phyir ro/l byis pa rnams la ni slu bar byed pa yin la/ de las gzhan pa rnams la ni sgyu ma la sogs pa Itar rten cing 'brel par 'byung ba nuid kyis kun rdzob tsam du 'gyur ro//

5 - brjod bya dang/ rjod byed dang/ shes pa dang/ shes bya la sogs pa'i tha ma lus pa 'di dag thams cad ni/ 'jig rten gyi kun rdzob kyi bden pa zhes bya'o//

6 - dngos po thams cad kyi rang gi ngo bo rnam pa gnyis nye bar gstan te/ 'di lta ste/ kun rdzob dang don dam pa'o

7 - It is important to bear in mind that Candrakïrti and Tsong khapa are different philosophers, with different projects and different views. This is particularly important as often when I quote or refer to views of Tsong khapa these views are articulated by him in the course of commenting on Candrakirti. So, sometimes, I will talk directly about Candrakirti, sometimes about Tsong khapa's own reading of Candrakīrti, sometimes about Tsong khapa's own view, and sometimes about my own, influenced by both of theirs.

8 - A note about my use of the word "foundationalism" is in order here. The term often is used only to denote an epistemological position according to which certain sentences or cognitive episodes are taken to be self-warranting and to stand as the foundation for all other knowledge. That is a foundationalism of content. But there is also a foundationalism of method, according to which certain faculties or methods of knowing are taken to be self-warranting and foundational. Descartes' use of clear and distinct perception in the Meditations is a good example of this kind of foundationalism. It is this latter kind of foundationalism that Nāgārjuna is here concerned to refute.

9 - re zhig gal te mngon sem gyis/ dngos rnam dmigs nas bzlog byed na/ gang gis dngos rnams dmigs 'gyur ba/ mngon sum de ni med ba yin// 
10 - "Suppose you were to say, after having apprehended everything by means of perception, that everything is empty. This rejection would make no sense! Why is that? Because, since perception-an epistemic instrument-must be included among everything, it would also be empty! And even the apprehender of these things would be empty! In that case, there would be no such thing as apprehension through an epistemic instrument. And since it makes no sense to reject that which is not even apprehended, the assertion that everything is empty wouldn't make any sense at all. Maybe you think that by using inference, scripture, or analogy you can reject everything you have apprehended."

gal te khyod kyis dngos po thams cad mngon sum gyi[s] dmigs nas dngos po thams cad ni stong pa'o zhes [b]zlog par byed na ni [mi] rung ngo [alt: nga]// de yang 'thad pa ma yin te/ ci'i phyir zhe na/ dngos po thams cad kyi nang du [ni] mngon sum gyi tshad ma yang 'dus pa'i phyir stong pa vyin la/ dngos po la dmigs par byed pa gang yin pa de yang stong pa yin [no]// de'i phyir [mngon sum gyi] tshad mas dmigs pa med do// mi dmigs pa 'gog pa yang mi 'thad pas de la dngos po thams cad ni stong pa'o zhes smras pa gang yin pa de 'thad pa ma yin no/ 'on te khyod kyi blo la rje sus dpag pa dang lung dang dpes [alt: sems] 'jal bas dmigs nas dngos po 'di thams cad [b]zlog par byed do snyam du sems na 'dir smra bar bya ste/ (Yonezawa 2008, 229:5-230:3)

11 - Once again, a terminological clarification is needed. The kind of coherentism Nāgārjuna is defending is not one in which all beliefs are mutually supportive, but rather one according to which the warrant of mechanisms of attaining knowledge and the warrant of the beliefs they deliver are mutually supportive.

12 - gal te rang las tshad ma grub/ gzhal bya rnams la ma ltos bar/ khyod kyi tshad ma 'grub 'gyur 'dil rang grub gzhan las Itos ma yin/l gal te gzhal bya'i don rnams la/ ma ltos khyod kyi tshad ma grub/ de Itar tshad ma 'di rnams ni/ gang gi'ang yin par mi 'gyur ro//

13 - 'on te khod kyi tshad grub pas/ gzhal bar bya ba 'grub 'gyur la/ gzhal bya grub pas tshad sgrub na/ khod kyi gnyis ka'ng 'grub mi 'gyur/l

14 - de'i phir de Itar tshad ma bzhi las 'jig rten gyi don rtogs par rnam par 'jog pa yin no//

15 - Note slight changes in the translation for greater clarity in this context.

16 - gti mug rang bzhin sgrib phyir kun rdzob ste/ des gang bcos ma bden par snang de ni/ kun rdzob bden zhes thub pa des gsungs te/ bcos mar gyur pa'i dngos ni kun rdzob tu'o//

Once again, note the use of obscurational, which is needed as a gloss of kun rdzob/samvrti to make sense of the gloss, instead of the standard conventional.

17 - Again, note slight translational differences. 
18 - Gnod pa med pa'i dbang po drug rnams kyis/gzung ba gang zhig 'jig rten gyis rtogs te/ 'jig rten nyid las bden yin Ihag ma ni/ 'jig rten nyid las log par rnam par gzhag//

\section{References}

Candrakīti. 1993. dBu ma la 'jug pa'i shad pa. Sarnath: Kagyu Relief and Protection Committee.

—_. 2003. dBu ma rtsa ba'i 'gral pa tshig gsal ba. Sarnath: dGe lugs pa Student Welfare Committee.

Garfield, Jay L. 2002. "Emptiness and Positionlessness: Do the Mādhyamika Relinquish All Views?" pp. 42-68. In J. Garfield, Empty Words. New York: Oxford University Press.

Loizzo, J. 2007. Nāgārjuna's Reason Sixty (Yuktișaștikā) with Candrakīrti's Commentary (Yuktișaștikavrtti). New York: Columbia University Press.

Thakchöe, S. 2007. The Two Truths Debate: Tsongkhapa and Gorampa on the Middle Way. Boston: Wisdom Publications.

. Unpublished. "Prāsaṇika Epistemology: Debate Between Tsongkhapa and his Critics on the use of Pramāṇa in Nāgārjuna's and Candrakīrti's Madhyamaka." University of Tasmania School of Philosophy.

Tsong khapa. 2006. Ocean of Reasoning: A Great Commentary on Nāgārjuna's Mūlamadhyamakakārikā. Translated by N. Samten and J. Garfield. New York: Oxford University Press. 